\title{
BINOMIAL FORMATION IN BADINI KURDISH WITH REFERNCE TO ENGLISH: A CONTRASTIVE STUDY
}

\author{
SAAED A. SAAed ${ }^{*}$ and HAVAl Ismail Ahmad Simo ${ }^{* *}$ \\ * Dept. of English, College of Basic Education, University of Duhok, Kurdistan Region-Iraq \\ ${ }^{* *}$ Dept. of English, College of Arts, University of Duhok, Kurdistan Region-Iraq
}

(Received: August 8, 2016; Accepted for Publication: October 9, 2016)

\begin{abstract}
The phraseological phenomenon of binomial pairing is a research topic that has captured the attention of many linguists. Recent research on binomials (e.g. Benor \& Levy, 2006) convincingly argues that studies on binomial pairing can generally be divided into two main types: studies on binomial order and studies on binomial formation. To the best of our knowledge, the latter type of studies dealing with binomial pairing in Badini Kurdish does not exist. Therefore, the present research is a pioneering attempt to fill in this research gap because it addresses the issue of binomial formation in Badini Kurdish binomials. It aims at achieving a detailed description of binomial formation and also at comparing and contrasting this topic in both Kurdish and English binomials. To fulfill these aims, the current study analyses a large number of Badini Kurdish binomials (302 pairs). The findings indicate that binomial formation in Badini Kurdish is a systematic process which is not very different from binomial formation in other languages as it shares the basic regulations required for forming a binomial, viz.: having two words which must be syntactically symmetrical and mostly connected by some sort of a lexical link. Although these regulations are very similar among both Badini Kurdish and English binomials, certain minor differences are also pointed out. Therefore, the study concludes by listing these similarities and differences in the binomial formation between Badini Kurdish and English binomials.
\end{abstract}

KEYWORDS: Binomial Pairing, Binomial Formation, Syntactically Symmetrical Pairs, Lexical Links in Binomials.

\section{INTRODUCTION}

$\mathbf{T}$ The present research focuses on the linguistic phenomenon of binomial pairing, e.g., man and woman, day and night. This topic has captured the attention of many linguists and in many languages. Malkiel (1959), who is the first originator of the term binomial, defines it as a "sequence of two words pertaining to the same form-class, placed on an identical level of syntactic hierarchy, and ordinarily connected by some kind of lexical link" (p.113). By and large, linguistic studies addressing up the topic of binomial pairing can be classified into two types: studies which examine the reasons for the order preference that the words manifest within the binomial phrase and studies which examine the overall structure of the binomial phrase. In the relevant literature, the former type of studies are known as studies of binomial order (Benor and
Levy, 2006) while the latter type of studies are known as studies of binomial formation (Benor and Levy, 2006; Mollin, 2012) or binomial construction (Masini, 2006). The main purpose of the current paper is to provide a description of the topic of binomial formation in the Kurdish language and specifically in Badini Kurdish (BK) on the basis of a large and varied amount of binomial pairs in the data analysed in the present study.

The paper is organised into 7 sections. Section 2 reviews the relevant literature. Section 3 states the aims of the current study. Section 4 introduces the data analysed in the current work. Section 5 provides a detailed description of the topic of binomial formation in English binomials. Section 6 discusses the topic of binomial formation in BK binomials. Section 7 concludes the paper. 


\section{LITERATURE REVIEW}

Although linguistic studies on Kurdish in general can hardly be found on different linguistic levels, studies on binomial pairing in Kurdish has not been a forgotten area since a few Kurdish linguists have examined this topic before. Among these studies are Salam (1977), Hamasoor (2007), Jameel (2013), and Saaed and Simo (2016). While Salam (1977) focuses on defining binomials, attempting to suggest an equivalent name in Kurdish and describing how the binomial can act as a semantic unit, Hamasoor (2007) is mainly interested in the classification of Kurdish binomials according to their parts of speech. For example, "were (came) and here (went)" is a binomial where a verb follows another verb while "sal bi sal" (year by year) is a binomial where a noun follows another noun and so on (pp. 120123). Jameel (2013) is an MA thesis which investigates binomials in BK. This investigation is limited to the study of the factors, namely semantic and pragmatic, which determine binomial ordering in Kurdish. Finally, Saaed and Simo (2016) is the most recent relevant study dealing with Kurdish binomials. This study provides quantitative-based evidence on the existence of 'the short-before-long preference tendency' in BK binomials.

A close consideration of the previous studies reveals that very little has been said about the structural features of binomials; the focus has been mainly on studying the process of binomial ordering. This is because attention has mainly been paid on the investigation of the factors that may determine the order of the words within the binomial. Jameel (2013) concentrates on the analysis of the semantic and pragmatic factors of ordering in BK binomials while Saaed and Simo (2016) address the question of the phonological factor of the short-before-long tendency of ordering. In other words, the main focus of the previous studies on Kurdish binomials has been laid on binomial order, not on binomial formation. Consequently, little has been said about the topic of binomial formation in Kurdish. The present study is therefore an attempt to fill in this research gap; it aims at providing a satisfactory coverage of this topic as it is shown in the following section.

\section{AIMS of THE STUDY}

1. The current study is a pioneering attempt to provide a detailed account of the process of binomial formation in BK. It seeks to find out the main structural properties that characterize binomial expressions and distinguish them from other types of expressions.

2. The second aim is to show the similarities and/or differences between the binomial formation in BK and English binomials.

\section{DATA}

The data examined in this research paper comprise a set of frequently used binomials in BK. They are largely based on the set of data gathered by Saaed and Simo (2016). But it has to be mentioned that several other pairs have been added to these. Therefore, the total number of the data made 302 binomial pairs. The nature of these data is observational, i.e., they have been collected through the observation made by native speakers (the researchers themselves, their families and friends) depending on their native-speaking competence and intuition. To further confirm the authenticity of the data, they were all reviewed by some colleagues specialized in Kurdish language.

\section{DESCRIPTION}

In this section we will look at the construction of the binomial phrase in order to gain an insight into the topic of binomial formation which is the focus of the present study. Let us first start by considering the most general feature of binomials, viz. its definition.

\subsection{Terms And Definitions}

The relevant literature shows that the term binomial is not generally agreed upon among linguists. As a result, various terms have been proposed in the relevant studies. This is clearly stated by Gustafsson (1975: 9) who points out that the subject of binomials is studied under "a herd of terms" in various "philological, linguistic and stylistic studies". Thus, Poutsma (1917) talks of hendiadys, Abraham (1950) of coordinates, Nash (1958) of paired words, Malkiel (1959) of binomials, Mellinkoff (1963) of doublings, Koskenniemi (1968) of repetitive word pairs, and Bolinger (1972) of repetition and intensification. 
In addition, the term freezes, which is originally suggested by Cooper and Ross (1975), is also used by several linguists as Oden and Lopes (1981), Ross (1982), Pordány (1986), Gil (1989), FenkOczlon (1989), Sobkowiak (1993) and Landsberg (1995) to refer to binomials. However, a close survey of the literature reveals that the most widely used term is Malkiel's (1959) binomials as it is the most frequently adopted term by many linguists. Among these are Gustafsson (1975), Oakeshott-Taylor (1984), Lambrecht (1984), Bhatia (1984; 1993), Norrick (1988), Klégr (1991) and Gold (1993). Besides, it is specifically the term binomials rather than any other that appears in the most recent relevant works by several linguists: Golenbock (2000), Masini (2006), Benor and Levy (2006), Ernestová (2007), Carvalho (2007), Klégr and Čermák (2008), Kopaczyk (2009), Lohmann (2011 \& 2012) and Mollin (2012). Likewise, the term binomials is the one preferred to be used in the present study. As for the justification for the choice of this term and also for the broad preference on retaining it, it might be the one given by Gustafsson (1975: 9): "This 'algebraic' term expresses the common denominator of this device: a binomial consists of two members which are in a parallel relation to one another".

We now move on to present the existing definitions of this phenomenon. In order to gain a clear idea of the main defining features of binomials, let us consider the main definitions proposed in the literature:

"[A binomial is] the sequence of two words pertaining to the same form-class, placed on an identical level of syntactic hierarchy, and ordinarily connected by some kind of lexical link"(Malkiel, 1959:113).

"A binomial consists of two members which are in parallel relation to one another" (Gustafsson,1975:9).

"A binomial is a sequence of two words which share specific syntactic and semantic relations with one another. The members of a binomial are usually syntactically coordinate words belonging to the same form-class, i.e. two nouns, verbs, or adjectives, etc. Their semantic relation is one of synonymy, opposition, complementation, or the like, e.g. null and void, up and down, bow and arrow" (Gustafsson, 1976:623).

"A binomial is a sequence of two words which belong to the same form-class and which are syntactically coordinated and semantically related" (Gustafsson, 1984: 123).

"A binomial consists of two lexemes, lexeme tokens, or phrases parallel on some level" (Norrick, 1988:74).

"A binomial is a sequence of two words belonging to the same form-class, connected by a conjunction or a preposition. The two components are placed on an identical level of syntactic hierarchy" (Alexander \& Plein, 1991:470).

"A binomial or multinomial expression is a sequence of two or more words or phrases belonging to the same grammatical category having some semantic relationship and joined by some syntactic device such as 'and' or 'or' "(Bhatia, 1994:143).

Having listed the main definitions existing in the literature, the next section will discuss the key defining properties of binomials.

\subsection{Formal Properties Of Binomials In English}

We now look at the formal properties of binomials which can be deduced from the abovementioned definitions. To begin with, the term formal properties is used here to refer to the structural features that characterize binomials, serve to distinguish them from other types of multiword expressions and thus divide them as a special category of multiword expressions. These structural features are the main building blocks of what is referred to as "binomial formation" (Benor and Levy, 2006). It is important to mention here that these structural features are not concerned with the topic of order preference (i.e. which word within the binomial gets the first place and which one gets the second place?). As is mentioned in the introduction, the topic of order preference is referred to in the literature as "binomial order" (Benor and Levy, 2006) which is not the concern of the present paper. Therefore, the present research is mainly concerned with binomial formation.

A close inspection of the definitions reveals that the binomials can be characterized by having the following formal features: (a) a binomial is composed of two paired words (dyadic expression); (b) the paired words should be of the same word-class; (c) the paired words are connected by a lexical link. In addition to these structural features, one might also mention the semantic features that are required for binomial formation. However, it has to be mentioned that the scope of the present research is limited to the 
description of the structural properties listed in (a), (b) and (c) above. This is because the semantics of binomials is too broad to be discussed here together with the structural properties. It is a topic that requires to be studied as a separate research paper on its own. In what follows we provide a further discussion of each of the features mentioned in (a), (b) and (c) above.

\subsubsection{Two Paired Words (Dyads)}

As we mentioned above, the title binomial itself obviously reflects the fact that this type of expression is composed of two words only, excluding the lexical link that comes in-between. Although all relevant studies in the literature agree that the pair of words plus a lexical link (i.e., word $1+$ link+word 2 as in man and woman) is the most widely occurring pattern in binomials, some studies show that examples containing more than two words do exist. Abraham (1950: 276) points out that English contains examples of binomial phrases bigger than a normal binomial pair because they are made of three or even four words, which he calls triplets and quadruplets respectively. Characteristic examples of these forms of triplets appear in (1) and of quadruplets in (2):

1. (a) deaf, dumb and blind

(b) man, woman, and children

(c) win, place and show

2. (a) earth, fire, water and air

(b) north, south, east, and west

Malkiel (1959: 120) agrees with this view and he further adds that binomial sequences of more than two words are quite possible to exist in many languages. Malkiel uses the term trinomials to refer to binomials made of three words and multinomials to refer to binomials made of more than three words. The following are the representative examples given by Malkiel:

3. (a) Tom, Dick, and Harry

(b) X, Y, and Z

(c) Ladies, Lords, and Gentlemen

Since Malkiel's multinomials are not limited to a specific number of words, it can be reasonably argued that various instances of long sequences of words such as days of the week, months of the year and the alphabet might be regarded as multinomials. Each of these contains a series of words happening in a fixed order and they are common to all languages. This might explain why some authors such as Chafe (1982) prefer to refer to trinomials by using the term series.

So far in our discussion we have shown that binomial expressions can comprise two or more than two words. However, the most frequent type is the binomial pair which is made of two words. We now need to show why binomials composed of a pair of words are most frequent in language. In an attempt to justify this phenomenon, Gustafsson (1975: 10) mentions some authors (e.g. Bendz, 1967; Havers, 1931) who ascribe the frequent use of binomials to "a common tendency towards duality, which makes a binomial an appropriate means of expressing synonymous and antonymous relations". This is in line with the statement made by Lyons (1977: 277) that there “... appears to be a general human tendency to categorize experience in terms of dichotomous contrasts". Therefore, we think that this view may justify both the existence of binomials as well as the preference to use them most frequently in language.

\subsubsection{Similar Word-Class}

The second basic formal property of the binomial is that both its component words should be syntactically symmetrical (Malkiel, 1959: 113). This means that the two paired words should belong to the same word-class. Scholars who studied English binomials provided various examples where almost all parts of speech are found conjoined together. The following are some of the characteristic examples chosen from the list of binomials suggested by Makkai (1972: 314-17) (parts of speech in brackets are provided by us):
4. (a) salt and pepper (noun + noun)
(b) do or die (verb + verb)
(c) fair and square (adjective + adjective)
(d) hither and thither (adverb + adverb)
(e) in and out (preposition + preposition)
(f) he and she (pronoun + pronoun)

(g) this and that (demonstrative pronoun + demonstrative pronoun)

However, exceptions to this rule of having syntactically symmetrical members may exist; Norrick (1988: 74) points out that it is possible to find examples where binomials "do not pertain to the same form-class". Here are some of his examples:
5. (a) by [preposition] and large [adjective]
(b) rough [adjective] and tumble [verb]
(c) up [preposition] and coming [verb]
(d) still [adjective] and all[noun]. 


\subsubsection{Lexical Link}

The third formal property of binomials is the link between the paired words. Binomial expressions are basically conjoined by a lexical link. Therefore, Abraham (1950) prefers to call them coordinates rather than binomials. In this section we will consider what sort of lexical link may exist between the paired words in binomials. As far as English binomials are concerned, Malkiel (1959: 129) states that "[t]he connective between the two members is typically a preposition or a conjunction: side by side, black and white". He further adds that the connective can be classified according to two factors: size and meaning. In terms of size, the most frequent range is the monosyllabic connective numbering up to three phonemes: and, by, on, or, to, but and the less frequent is the disyllabic: after, against. In terms of meaning, Malkiel (1959: 130) sets apart three types of relationships in the following order of decreasing frequency: (a) conjunction proper as in: rats and mice, this and that, town and gown; (b) alternative as in: all or nothing, heads or tails, sooner or later; (c) disjunction as in: neither chick nor child, neither kith nor kin, neither fish nor fowl.

The existence of similar linkage patterns have been noted in other languages as well. Lambrecht (1984: 768) ascertains the existence of the same three linking patterns in German binomials with the conjunction und 'and' as being the most frequent one. Shivtiel (2008: 631) thinks the same about the lexical link in Arabic binomials; he proposes that the following links are possible to occur in Standard Arabic binomials:

6. (a) Without any link, e.g. /xaraab jabaab/ 'complete destruction'

(b) Linked by a conjunction, e.g. / ?axð wa-radd/ 'discussion, debate'

(c) Linked by a preposition, e.g. /ra?s ৎalaa Saqib/ 'upside down'

(d) Both linked by prepositions, e.g. /min ?awwalihi Pilaa Paaxirihi/ 'from A to Z'

(e)Linked by a preposition and a conjunction, e.g. /bi-1-baa؟ wa-ð-ðiraą/ 'with might and main'

(f) Preceded by a negative particle and linked by a conjunction, e.g. /laa fatiil wa-laa naqiir/ 'nothing' (g) Preceded by a preposition and a negative particle and a conjunction followed by a negative particle, e.g. /bi-laa kitaab wa-laa sunna/ 'lawlessness'
In a more recent fine-grained investigation of Arabic binomials, Saaed (2013) observes the need to add two important points to Shivtiel's abovementioned list. The first one is that the alternative conjunction / Paw/'or' can be added to the list in (6) because it is also commonly used in Arabic as in /maSa Paw didd/ 'with or against'. The second one is that these links seem to have the following frequency order: the conjunction and is the most frequent link, the disjunctive or is the next frequent one, while the remaining links are less frequent. Consequently, it seems that the same pattern of the three types of relations among connectives described by Malkiel along with the same order of frequency observed for English binomials is also regular in Arabic and German. In his attempt to find a plausible answer to the question of why certain links, in particular the conjunction and the disjunction, are more frequent than others, Lambrecht (1984) suggests that this is motivated by a general rule which he mentions as follows: "the more we depart from the logical connectors [i.e. and or], the looser and the more adverb-like the link, the less acceptable the binomial expression becomes" (p.768). Therefore, he prefers to call them logical connectors.

\section{FORMAL PROPERTIES Of BINOMIALS IN BADINI KURDISH}

We now look at binomial formation in BK. In the following subsections, we provide a detailed description of the formal properties of the binomials in our data.

\subsection{Two Paired Words}

By and large, all the binomials in our data are dyadic (see appendix). The pairs in (7) contain some of the representative examples:

7. (a) nêr u mê (male and female)

(b) reş u spî (black and white)

(c) germ u nerm (hot and soft)

(d) dil $\mathrm{u}$ can (heart and soul)

(e) kanî u rîbar (spring and river)

But how about the existence of trinomials and multinomials in BK? We mentioned in (5.2.1) above that multi-word expressions which are bigger than binomials do exist in English but not as frequently as binomials. Do they exist in BK? We have not come across instances of trinomials or multinomials in BK. Therefore, we would like to draw the first conclusion in this research that binomial formation in $\mathrm{BK}$ is restricted to dyadic 
expressions only. This is different from English binomials where the number of words is not restricted to dyads only but can extend to three and more words as discussed in (5.2.1) above.

\subsection{Similar Word-Class}

Our findings indicate that Kurdish binomials display a strong tendency to have syntactically symmetrical members. As discussed in (5.2.2) above, this implies that the paired words should both belong to the same word-class. All the examples in the binomials in our data are syntactically symmetrical. Here are some representative examples:
8.

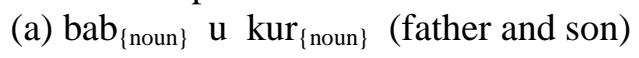

(b) bwîk \{noun\} $_{\text {u zava }}$ \{noun\} $($ bride and groom)

(c) $\operatorname{ser}_{\{\text {noun }\}}$ u pêt $\hat{e}_{\{\text {noun\} }} \quad$ (head and foot)

(d) $\operatorname{befir}_{\{\text {noun }\}} \mathrm{u}$ baran \{noun\} $_{\text {(snow and rain) }}$

(e) xwîş $_{\{\text {noun\} }} \mathrm{u}$ bira ${ }_{\{\text {noun\} }}$ (sister and brother)

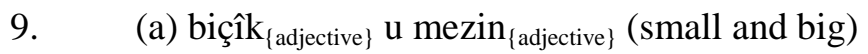

(b) reş \{adjective\} $\mathbf{u}$ spî $\hat{1}_{\text {\{adjective\} }}$ (black and white)

(c) $\operatorname{kurt}_{\{\text {adjective\} }} \mathrm{u}$ dirêj $\hat{j}_{\{\text {adjective\} }}$ (short and tall)

(d) $\operatorname{sar}_{\text {\{adjective\} }} u$ germ \{adjective\} $_{\text {(a) }}$ (cold and hot)

10. (a) $\operatorname{bixu}_{\{\text {verb\} }}$ u vexu verb\} $_{\text {(eat }}$ (eand drink)

(b) here $\{$ verb\} $\mathrm{u}$ were $\{$ verb\} $\}$ (go and come)

(c) rabe $_{\{\text {verb\} }}$ u rîne \{verb\} (stand up and sit down)
11. (a) ber (adverb\} $_{\text {u pişt }}$ adverb $\}_{\text {(front and back) }}$

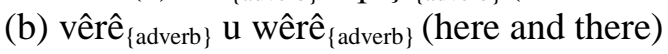

12. $\mathrm{eZ}_{\{\text {pronoun\} }} \mathrm{u} \mathrm{tu}_{\{\text {pronoun }\}}(\mathrm{I}$ and you)

The examples listed in 8-12 above may illustrate two important points. The first point is the fact that binomials in BK exhibit a strong tendency to have syntactically symmetrical members of almost all the basic parts of speech: nouns, adjectives, verbs, adverbs and pronouns. This is very much compatible with the findings made in the literature for other languages. However, it should be mentioned that BK binomials are different from English binomials in that they do not allow any exception to the rule of having syntactically symmetrical words; this is because our data do not contain any cases of binomials where the two members belong to two different word-classes. The second point has to do with the frequency of occurrence in that not all parts of speech are equally frequent in their occurrence. The decreasing number of examples shown in 8-12 above reflects the occurrence frequency of the binomials in our data with the noun plus noun formula being the most frequent one and the pronoun plus pronoun formula being the least frequent one. The following table shows the exact number of the binomial pairs for each part of speech as observed in the binomials analyzed in our data:

Table (1): Parts of speech of BK binomials and their frequency of occurrence

\begin{tabular}{cccc}
\hline \multirow{2}{*}{ No. } & \multicolumn{2}{c}{ Parts of Speech } & Percentage \\
\cline { 2 - 3 } & Type & $\begin{array}{c}\text { Number } \\
\text { of Pairs }\end{array}$ & \\
\hline 1 & Noun+Noun & 223 & $74 \%$ \\
\hline 2 & Adjective+Adjective & 37 & $12 \%$ \\
\hline 3 & Verb+Verb & 19 & $6 \%$ \\
\hline 4 & Adverb+Adverb & 18 & $6 \%$ \\
\hline 5 & Pronoun+ Pronoun & 5 & $2 \%$ \\
\hline & Total number & 302 & 100 \\
\hline
\end{tabular}

As can be seen in the table, the occurrence of the noun plus noun pattern is the highest in our data (74\%), followed by the adjective plus adjective (12\%), followed by the verb plus verb and the adverb plus adverb which both have exactly the same percentage of occurrence (6\%), 
and followed by the pronoun plus pronoun pattern with the least frequency percentage (2\%).This finding is in line with a similar finding made in the relevant literature by Gorgis and Al-Tamimi (2005) who studied binomials in Iraqi and Jordanian dialects and observed that the noun plus noun pattern is the most frequent in their data.

\subsection{Lexical Link}

According to the findings of the present study, the lexical link seems to be a basic element in the construction of a binomial phrase in BK. By and large, BK binomials tend to be conjoined by a link. The binomials analysed in our data contain various types of links. The first type of lexical link which is found widely common in our data is the conjunction and as can be seen in the following examples:
13. (a) nêr u mê (male and female)
(b) mirin u jiyan (death and life)
(c) dexl u dan (wheat and grain)

The second type of link found in BK binomials is the disjunction link in its both forms: either ...or and neither ...nor. Consider these examples:
14. (a) yan noke yan paşî (either now or later) (b) ne hêrve u ne wêve (neither here nor there)

The alternative link or is also found:

15. (a) eve yan dî (this or the other)

(b) kêm yan zêde (little or much)

The other type of link observed in our data is the preposition by as in:

16. (a) êk bi êk (one by one)

(b) roj bi roj (day by day)

Finally, it is also possible to form a binomial phrase in BK without having any link. The binomials in the following examples contain no connective element at all:

17. (a) xir xir (i.e. snoring)

(b) hir hir (i.e. shouting)

It has to be mentioned that not all of these sorts of link are similarly frequent. Our statistical findings strongly confirm that the conjunction and is the most frequent type of lexical link in BK binomials. All the remaining sorts of link are remarkably less frequent as can be inferred from the number of occurrence of each link listed in the following table:

Table (2): The types of links and their occurrence frequency in BK binomials

\begin{tabular}{ccc}
\hline No. & \multicolumn{2}{c}{ A list of Possible Links in BK } \\
\cline { 2 - 3 } & Type & $\begin{array}{c}\text { Number of } \\
\text { occurrence }\end{array}$ \\
\hline 1 & And & 270 \\
\hline 2 & Neither ... nor & 10 \\
\hline 3 & (Either) ... or & 6 \\
\hline 4 & Or & 4 \\
\hline 5 & Zero Conj & 9 \\
\hline 6 & By & 3 \\
\hline & Total number & 302 \\
\hline
\end{tabular}

Based on this finding, we may conclude that BK binomials are not different from those of other languages in that there is a strong tendency to have a lexical link in the binomial phrase. The types of the links commonly used are similar to the three types of relations among lexical links described by Malkiel (see 5.2.3): conjunction, alternative and disjunction. Moreover, the frequency order is also more or less similar to that found in other languages with the conjunction and being the most frequent one.

\section{CONCLUSIONS}

The current study draws the following conclusions: 1. The process of binomial formation in $B K$ is systematic. It is based on certain regulations which are highly similar to those found active in the binomial formation of other languages. Thus, to form a genuine binomial in $\mathrm{BK}$, we need to 
have a pair of words which should be syntactically symmetrical and frequently joined by a lexical link.

2. The regulations which achieved the highest frequency of occurrence in BK binomials are being dyadic, having a noun plus noun pattern, and being connected by the conjunction and. The high frequency of occurrence of these regulations is compatible with the high frequency of occurrence of the same regulations in the binomial formation of other languages.

3. In an attempt to compare and contrast binomial formation in BK and English, the study concludes that in general binomial formation is similar in both languages. Both languages follow the regulations mentioned above. However, some differences are spotted: Unlike English, BK does not contain phrases bigger than binomials such as trinomials and mutlinomials. Also, in BK the words of the binomial are always syntactically symmetrical while in English it is possible to have a binomial in which the words are not syntactically symmetrical.

\section{BIBLIOGRAPHY}

- Abraham, R. D. (1950). Fixed order of coordinates: A study in comparative lexicography. Modern Language Journal, 34, pp. 276-287.

- Alexander, R., \& Plein, U. (1991). Pairing up:

Didactic and contrastive considerations of irreversible binomials in German and English. Die Neueren, 90(5), pp. 467-481.

\begin{tabular}{|c|c|c|c|c|c|c|}
\hline $\begin{array}{l}\text { Lexical } \\
\text { Link }\end{array}$ & $\begin{array}{l}\text { Parts of } \\
\text { Speech }\end{array}$ & $\begin{array}{l}\text { Idiomatic } \\
\text { Translation }\end{array}$ & $\begin{array}{c}\text { Literal } \\
\text { Translation }\end{array}$ & Latin & $\begin{array}{c}\text { Kurdish } \\
\text { Binominals }\end{array}$ & \\
\hline And & $N+N$ & $\begin{array}{c}\text { Sense of } \\
\text { Thankfulness }\end{array}$ & Head \& Eye & ser u çav & سةر و ضاظ & 1 \\
\hline And & $A d v+A d v$ & $\begin{array}{c}\text { All sides } \\
\text { (All details) }\end{array}$ & Top \& Bottom & ser u bin & سةر و بن & 2 \\
\hline and & $\mathrm{N}+\mathrm{N}$ & & Head \& Foot & ser u pê & ستةر و ثَنَ & 3 \\
\hline and & $\mathrm{N}+\mathrm{N}$ & Dependency & Hand \& Foot & dest u pê & دةقست و ثيَ & 5 \\
\hline and & $A d v+A d v$ & & Front \& Back & ber u pişt & بةز و ثشت & $\underline{6}$ \\
\hline and & $\mathrm{N}+\mathrm{N}$ & & Bosom \& Front & sîng u ber & سينطو بةر & 7 \\
\hline and & $\mathrm{N}+\mathrm{N}$ & & Eye \& Eyebrow & çav u birî & ضاظو برى & 8 \\
\hline
\end{tabular}

\begin{tabular}{|c|c|c|c|c|c|c|}
\hline and & Pro + Pro & & I \& You & ez u tu & نئز و تو & 9 \\
\hline and & $\mathrm{N}+\mathrm{N}$ & & Male \& Female & nêr u mê & نَيَر و مئ & 10 \\
\hline and & $\mathrm{N}+\mathrm{N}$ & & Bride \& Groom & bwîk u zava & بويك و زاظا & 11 \\
\hline and & $\mathrm{N}+\mathrm{N}$ & & Wife \& Husband & jin u mêr & ذَن و ميَر & 12 \\
\hline and & $\mathrm{N}+\mathrm{N}$ & Parents & Mother \& Father & deyk u bab & دثيك و باب & 13 \\
\hline and & $\mathrm{N}+\mathrm{N}$ & & Uncle \& Nephews - Nieces & xal u xwarza & خال و خوارزا & 14 \\
\hline and & $\mathrm{N}+\mathrm{N}$ & & Uncle \& Nephews - Nieces & mam u braza & مام و برازا & 15 \\
\hline and & $\mathrm{N}+\mathrm{N}$ & & Sister \& Brother & xwîşk u bira & خويثك و برا & 18 \\
\hline and & $A d j+A d j$ & & Small \& Big & biçîk u mezin & بضيك و مةزن & 19 \\
\hline and & $\mathrm{N}+\mathrm{N}$ & & Drum \& Clarinet & dehol u zirna & دة اهول و زرنا & 20 \\
\hline and & $\operatorname{Adj}+\operatorname{Adj}$ & & Black \& White & reş u spî & ر رةش و سثى & 21 \\
\hline and & $\mathrm{N}+\mathrm{N}$ & & Affection \& Love & èşq u viyan & عتشق و ظيان & 22 \\
\hline and & $\mathrm{N}+\mathrm{N}$ & Faithfulness & Bread \& Salt & nan u xwê & نان و خويَ & 26 \\
\hline and & $A d j+A d j$ & & Short \& Tall & kurt u dirêj & كورت و دريَذ & 27 \\
\hline
\end{tabular}




\begin{tabular}{|c|c|c|c|c|c|c|}
\hline and & $\mathrm{N}+\mathrm{N}$ & & Death \& Life & mirin u jiyan & مرن و ذيان & 28 \\
\hline and & $A d v+A d v$ & $\begin{array}{c}\text { Dice game, } \\
\text { Behave randomly }\end{array}$ & Six \& Five & eş u bêşş & شتش و بيَش & 29 \\
\hline and & Adj + Adj & & Unstick \& Askew & sist u xar & ستت و خوار & 31 \\
\hline and & $\mathrm{N}+\mathrm{N}$ & & trees & dar u bar & دار و بار & 32 \\
\hline and & $\mathrm{N}+\mathrm{N}$ & & Poppies & helal u beybîn & هةلال و بتييين & 33 \\
\hline and & $\mathrm{N}+\mathrm{N}$ & & Concern \& Depression & xem u kuvan & خةم و كوظان & 36 \\
\hline and & $\mathrm{N}+\mathrm{N}$ & & Groan \& Regret & ax $u$ of & ئاخ و ئوف & 37 \\
\hline and & $\mathrm{N}+\mathrm{N}$ & Sense of Sadness & Inflammation \& Depression & kul u kuvan & كول و كوظان & 38 \\
\hline and & Adj + Adj & Sense of Laziness & Motionless & sist u pist & سست و شت & 39 \\
\hline and & $\mathrm{N}+\mathrm{N}$ & & Exigencies & kel u pel & كةل و ثنت & 40 \\
\hline and & $\mathrm{N}+\mathrm{N}$ & & Boughs & eq u meqç & ضةقق و منق & 44 \\
\hline and & $A d v+A d v$ & & Hastiness & lez u bez & للةز و بةز & 45 \\
\hline and & $\mathrm{N}+\mathrm{N}$ & Simple Things & Things & xir u mir & خر و مر & 46 \\
\hline and & $\mathrm{N}+\mathrm{N}$ & Place of Residence & House \& Survival & xan u man & خان و مان & 47 \\
\hline and & $\mathrm{N}+\mathrm{N}$ & Real Estates & House \& front & xan $u$ ber & خان و بةر & 48 \\
\hline and & $\mathrm{N}+\mathrm{N}$ & Simple Things & Things & tişt u mişt & تشت و مشت & 49 \\
\hline and & Adj + Adj & & Alive \& Healthy & sax u selîm & ساخ و سةليم & 50 \\
\hline and & $\mathrm{N}+\mathrm{N}$ & Simple Things & Boscages & deẍel u meẍel & دةقغةل و مةغغل & 51 \\
\hline and & $\mathrm{N}+\mathrm{N}$ & & Wheat \& Grain & dexl u dan & دةخل و دان & 52 \\
\hline and & $\operatorname{Adj}+\operatorname{Adj}$ & & Red \& White & sor u spî & سور و سثى & 53 \\
\hline and & $A d v+A d v$ & Destiny & Head \& Place & ser u şwîn & سةر و شوين & 60 \\
\hline and & $\operatorname{Adj}+\operatorname{Adj}$ & & Pretty & ux u şeng ş & شوخ و شتنط & 61 \\
\hline and & $\operatorname{Adj}+\operatorname{Adj}$ & Two Friends & Young Goats & zeng $\mathrm{u}$ beng & زةتط و بتنط & 62 \\
\hline and & $\mathrm{N}+\mathrm{N}$ & $\begin{array}{c}\text { Beautiful Maidens live } \\
\text { in Paradise }\end{array}$ & Houris & zerî u perî & زمةى و ثثرى & 63 \\
\hline and & $V+V$ & Traffic & Come \& Go & hat $u$ çu & هات و ضوو & 64 \\
\hline and & $\mathrm{N}+\mathrm{N}$ & & Farm \& Sheep & rez u pez & ر رةز و ثثز & 65 \\
\hline and & $\mathrm{N}+\mathrm{N}$ & & Obsequies & n u tazîşî & شين و تازى & 66 \\
\hline and & $\mathrm{N}+\mathrm{N}$ & & Wish \& Hope & hîvî u omêd & هيظى و ئوميَّ & 67 \\
\hline and & $\mathrm{N}+\mathrm{N}$ & & Goose \& Pike & qaz u quling & قاز و قولنط & 68 \\
\hline and & $\mathrm{N}+\mathrm{N}$ & & Plain \& Resort & deşt u zuzan & ل & 69 \\
\hline and & $\mathrm{N}+\mathrm{N}$ & Diaries & $\&$ Cheese Variety of Cheese & jajî u penîr & ذاذى و ثنةنير & 70 \\
\hline and & $\mathrm{N}+\mathrm{N}$ & & Bread \& Yogurt & nan u mast & نان و ماست & 71 \\
\hline and & $\operatorname{Adj}+\operatorname{Adj}$ & & Cold \& Hot & sar u germ & سار و طةرم & 72 \\
\hline and & $\mathrm{N}+\mathrm{N}$ & News & Sound \& Subject & deng u bas & دةثط و باس & 73 \\
\hline and & $\operatorname{Adj}+\operatorname{Adj}$ & & Crazy \& Naughty & dîn u har & دين و هار & 74 \\
\hline and & $\operatorname{Adj}+\operatorname{Adj}$ & & Curvature & xar u vîç & خار و ظيض & 75 \\
\hline
\end{tabular}




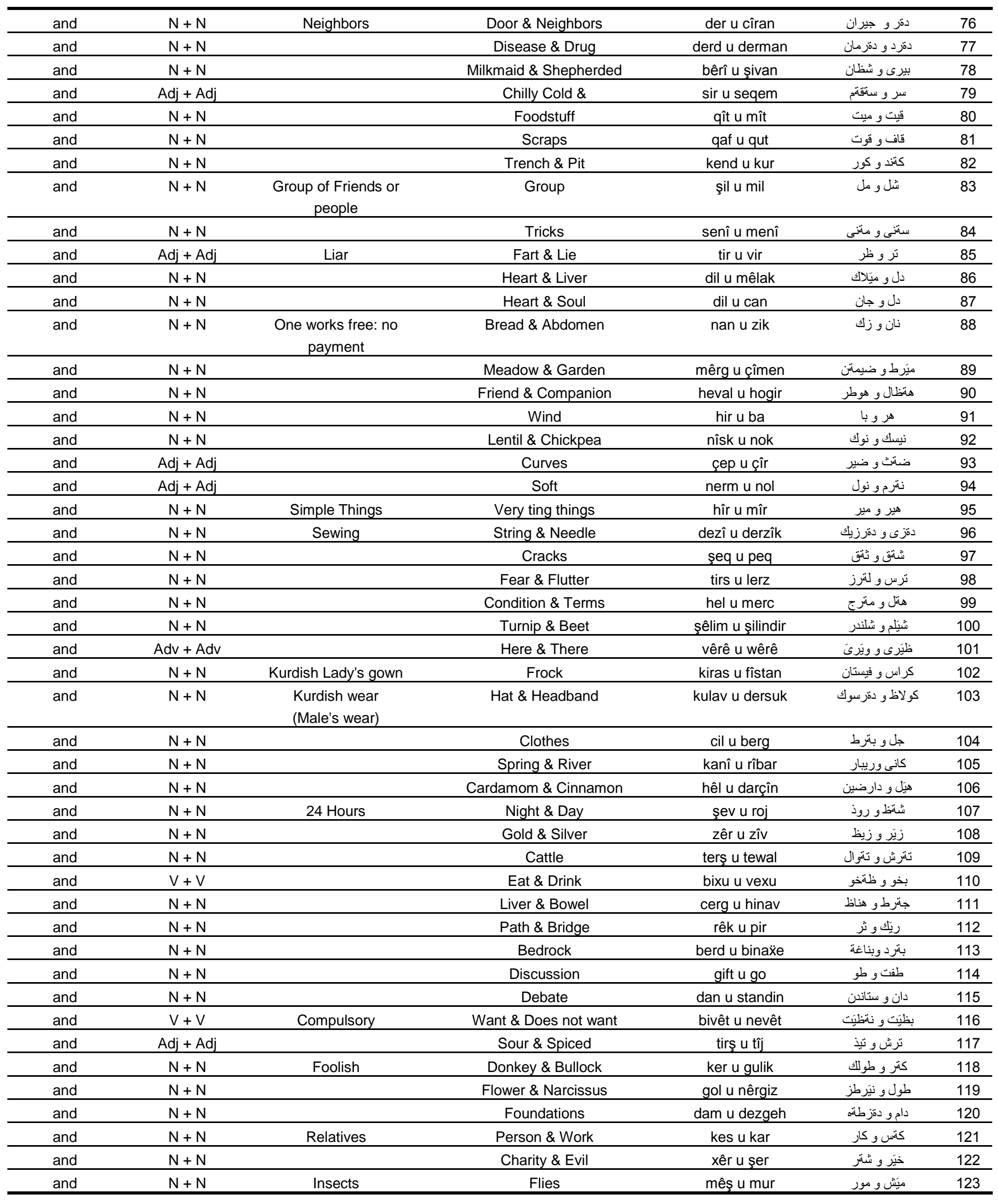




\begin{tabular}{|c|c|c|c|c|c|c|}
\hline and & $A d v+A d v$ & & Climbing \& Descending & jêhel u jurda & ذيَهَتل و ذووردا & 124 \\
\hline and & Adj + Adj & Authentication & Straight \& Right & rast $u$ dirust & راست و دروست & 125 \\
\hline and & Adj + Adj & & Wet \& Dry & ter u hişk & تنةر و هشك & 126 \\
\hline and & $\mathrm{N}+\mathrm{N}$ & & Charity \& Joy & xêr u xoşî & خ خيَر و خوشى & 128 \\
\hline and & $\mathrm{N}+\mathrm{N}$ & Kurdish Epic & Person's name \& Person's name & mem u zîn & مةم و زين & 129 \\
\hline and & $\mathrm{N}+\mathrm{N}$ & Kurdish Epic & Person's name \& Person's name & şirîn u ferhad & شرين و فر هاد & 130 \\
\hline and & $\mathrm{N}+\mathrm{N}$ & & God \& Prophet & xodê u pêxember & خوديَ و ثيَغَتمبةر & 133 \\
\hline and & $\mathrm{N}+\mathrm{N}$ & Food meal & Rice \& Soup & birinc $u$ avik & برنج و ناظلك & 134 \\
\hline and & $\mathrm{N}+\mathrm{N}$ & Possessions & Circumstance \& House & al u mall & حال و مال & 135 \\
\hline and & Adj + Adj & & Little \& Much & kêm u zêde & كيَم و زيَدة & 136 \\
\hline and & $\mathrm{N}+\mathrm{N}$ & & Beard \& Mustache & rîh u simbêl & ريه و سمبيَل & 137 \\
\hline and & $\mathrm{N}+\mathrm{N}$ & & Origin \& Tribe & esl u îcax & نئةسل و نيجاخ & 141 \\
\hline and & $\mathrm{N}+\mathrm{N}$ & Agriculture & General \& Old & gist u kal & طشت و كال & 142 \\
\hline and & $\mathrm{N}+\mathrm{N}$ & & Travel \& Tourism & geşt u gozar & طنشت و طوزار & 143 \\
\hline and & $\mathrm{N}+\mathrm{N}$ & & Flower \& Rose & gol u golzar & طول و طولز ار & 144 \\
\hline and & $\mathrm{N}+\mathrm{N}$ & & Saying \& Lesson & gut $u$ bend & طوت و بنتد & 145 \\
\hline and & $\mathrm{N}+\mathrm{N}$ & & Fear \& Hunger & tirs u birs & ترس و برس & 146 \\
\hline and & $\mathrm{N}+\mathrm{N}$ & & Deficiencies & kêm u kasî & كيَّ و كاسى & 147 \\
\hline and & $\mathrm{N}+\mathrm{N}$ & & Mother in Law \& Father in Law & xesî u xezîr & ختشى و خةزير & 148 \\
\hline and & $\mathrm{N}+\mathrm{N}$ & & Village's Name \& Village's Name & sîyar u spîndar & سبار و سثيندار & 149 \\
\hline and & $\mathrm{N}+\mathrm{N}$ & & Village's Name \& Village's Name & bank u eriz & بانك وئةرز & 150 \\
\hline and & $\mathrm{N}+\mathrm{N}$ & Simple things & Small Parts & pirt u mirt & ترت مرت & 157 \\
\hline and & $\mathrm{N}+\mathrm{N}$ & & Finger \& Foot & til u pê & 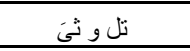 & 158 \\
\hline and & $\mathrm{N}+\mathrm{N}$ & & Valleys & dol u nihal & 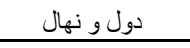 & 159 \\
\hline and & $\mathrm{N}+\mathrm{N}$ & Noise & Slap \& Sound & şeq u dûq & ش شةق و دووق & 160 \\
\hline and & $\mathrm{N}+\mathrm{N}$ & Noise & Slap \& Solid & şeq u req & شخقق و رمق & 161 \\
\hline and & $\mathrm{N}+\mathrm{N}$ & Beating & Slap \& Kick & şeq u pên & شاقق و ثيَن & 162 \\
\hline and & $A d v+A d v$ & Environment & Around \& Near & dewr u ber & دقور و بةر & 163 \\
\hline and & $\mathrm{N}+\mathrm{N}$ & & Laughing & tîq u lîq & تيق و ليق & 164 \\
\hline and & $\mathrm{N}+\mathrm{N}$ & Simple things & Small Parts & qîç u mîç & قيض و ميض & 165 \\
\hline and & Adj + Adj & & Naked & rîs u çîmlaq & ريس و ضيملاق & 166 \\
\hline and & $\mathrm{N}+\mathrm{N}$ & & Nut \& Almond & gîz u bahîv & طيز و باهيظ & 167 \\
\hline and & $\mathrm{N}+\mathrm{N}$ & & Survival \& Annihilation & man u neman & مان و نتةمان & 168 \\
\hline and & $N+N$ & $\begin{array}{l}\text { Sound of Breaking } \\
\text { such as Thunder }\end{array}$ & Sound & irîq u pirîqş & شريق و شريق & 169 \\
\hline and & $A d v+A d v$ & Accurate & Meter \& Exact & fît u fîtlan & فيت و فيتلان & 170 \\
\hline and & $\mathrm{N}+\mathrm{N}$ & & Tone \& Poetry & awaz u hozan & ئاو از و هوزان & 171 \\
\hline and & $\mathrm{N}+\mathrm{N}$ & & Leg \& Calf & ling u pîq & لنطو ثيق & 172 \\
\hline
\end{tabular}




\begin{tabular}{|c|c|c|c|c|c|c|}
\hline and & $\mathrm{N}+\mathrm{N}$ & & Garlic \& Onion & sîr u pîvaz & سير و ثيظاز & 173 \\
\hline and & Adj + Adj & & Flexible \& Resilient & nerm u helîm & نة نةرم ح حقليم & 174 \\
\hline and & $\mathrm{N}+\mathrm{N}$ & & Respect \& Greeting & rêz u silav & ريَز وسلاظ & 175 \\
\hline and & $\mathrm{N}+\mathrm{N}$ & & Looker \& Listener & bîner u gohdar & بينةر و طو هدار & 177 \\
\hline and & $\mathrm{N}+\mathrm{N}$ & & Rider \& Walker & sîyar u peya & سبار و ثثةيا & 178 \\
\hline and & $\mathrm{N}+\mathrm{N}$ & & Grinding \& Plough & distar u hevcar & دستار و هتظجار & 179 \\
\hline and & $\mathrm{N}+\mathrm{N}$ & & Tobacco \& Pipe & tîtin u qelîn & تبتن و قةلين & 181 \\
\hline and & $\mathrm{N}+\mathrm{N}$ & & Lance \& Bow & tîr u kivan & تير و كظان & 182 \\
\hline and & $\mathrm{N}+\mathrm{N}$ & Condition & Hand \& Wood & dest u dar & دةتست و دار & 183 \\
\hline and & $A d v+A d v$ & & Scattered & tera u bera & تنة او بةرا & 184 \\
\hline and & $\mathrm{N}+\mathrm{N}$ & & Plain \& Mountain & deşt u çiya & دةثت و ضبا & 185 \\
\hline and & $\mathrm{N}+\mathrm{N}$ & & Tillage Steering \& Plough & nîrik u hevcar & نيرك و هذظجار & 186 \\
\hline and & $\mathrm{N}+\mathrm{N}$ & & Wind \& Storm & ba u barov & 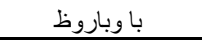 & 189 \\
\hline and & $\mathrm{N}+\mathrm{N}$ & & Obsequies \& Happiness & Şîn u şadî & شين وشادى & 190 \\
\hline and & $\mathrm{N}+\mathrm{N}$ & & Hatred & kerb u kîn & كةرب و كين & 191 \\
\hline and & $\mathrm{N}+\mathrm{N}$ & & Father \& Grandfather & bab u kal & باب و كال & 192 \\
\hline and & $\mathrm{N}+\mathrm{N}$ & & Plait & kezî u bisk & كةزى و بسك & 193 \\
\hline and & $\mathrm{N}+\mathrm{N}$ & Running of Time & Time \& Rotation & dem u dewran & دةم و دةور ان & 194 \\
\hline and & $\mathrm{N}+\mathrm{N}$ & & Ornamenting \& Scarf & xeml u xêl & خةمل و خيّل & 195 \\
\hline and & $\mathrm{N}+\mathrm{N}$ & & Meadow \& Garden & Mêrg u bä̈ & ميَرطو باغ & 196 \\
\hline and & $\mathrm{N}+\mathrm{N}$ & & Iris \& Spike of a grain & susin u sunbil & سوسن و سونبل & 197 \\
\hline and & $\mathrm{N}+\mathrm{N}$ & & Poverty & jar u jwîrî & ذذار و ذويرى & 198 \\
\hline and & $\mathrm{N}+\mathrm{N}$ & & Pain \& Cramp & êş u jan & يُبَش و ذان & 206 \\
\hline and & $\mathrm{N}+\mathrm{N}$ & & Guesthouse & kuçik u dîwan & كوضك و ديوان & 207 \\
\hline and & $\mathrm{N}+\mathrm{N}$ & & Servants & xulam $\mathrm{u}$ xidam & خو لام و خدام & 208 \\
\hline and & $\mathrm{N}+\mathrm{N}$ & Confusion & Fog & mij u moran & مذو موران & 209 \\
\hline and & $\mathrm{N}+\mathrm{N}$ & & Mountain & çel u çiya & ضشةل و ضيا & 210 \\
\hline and & $\mathrm{N}+\mathrm{N}$ & & Dancing & govend u dîlan & طوظةند و ديلان & 211 \\
\hline and & $\mathrm{N}+\mathrm{N}$ & & Problems & gîr u girift & طير و طرفت & 212 \\
\hline and & $V+V$ & & Go \& Come & here u were & هةرة و وةرة & 213 \\
\hline and & $\mathrm{N}+\mathrm{N}$ & & Month \& Year & heyv u sal & هقيظ وسال & 214 \\
\hline and & $\mathrm{N}+\mathrm{N}$ & & Saturday \& Sunday & şembî u êkşemb & 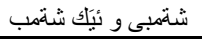 & 215 \\
\hline and & $\mathrm{N}+\mathrm{N}$ & & Meat \& Blood & goşt u xwîn & طوشت و خوين & 216 \\
\hline and & Adj + Adj & & Aged \& Grandfather & pîr u kal & 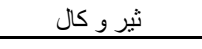 & 217 \\
\hline and & $V+V$ & & Come \& Doesn't Come & hat u nehat & هات و نةهات & 218 \\
\hline and & $\mathrm{N}+\mathrm{N}$ & & Money \& Stamp & pare u pul & ثارة و ثول & 219 \\
\hline and & $\mathrm{N}+\mathrm{N}$ & Flumes & Water \& Pipes & av u sulîn & ئاظ و سولين & 220 \\
\hline and & $\mathrm{N}+\mathrm{N}$ & & Gold \& Adornment & zêr u zînet & زيَر و زينةت & 221 \\
\hline and & $\mathrm{N}+\mathrm{N}$ & & Concerns & xem u xefet & خةم و خةفةت & 222 \\
\hline
\end{tabular}




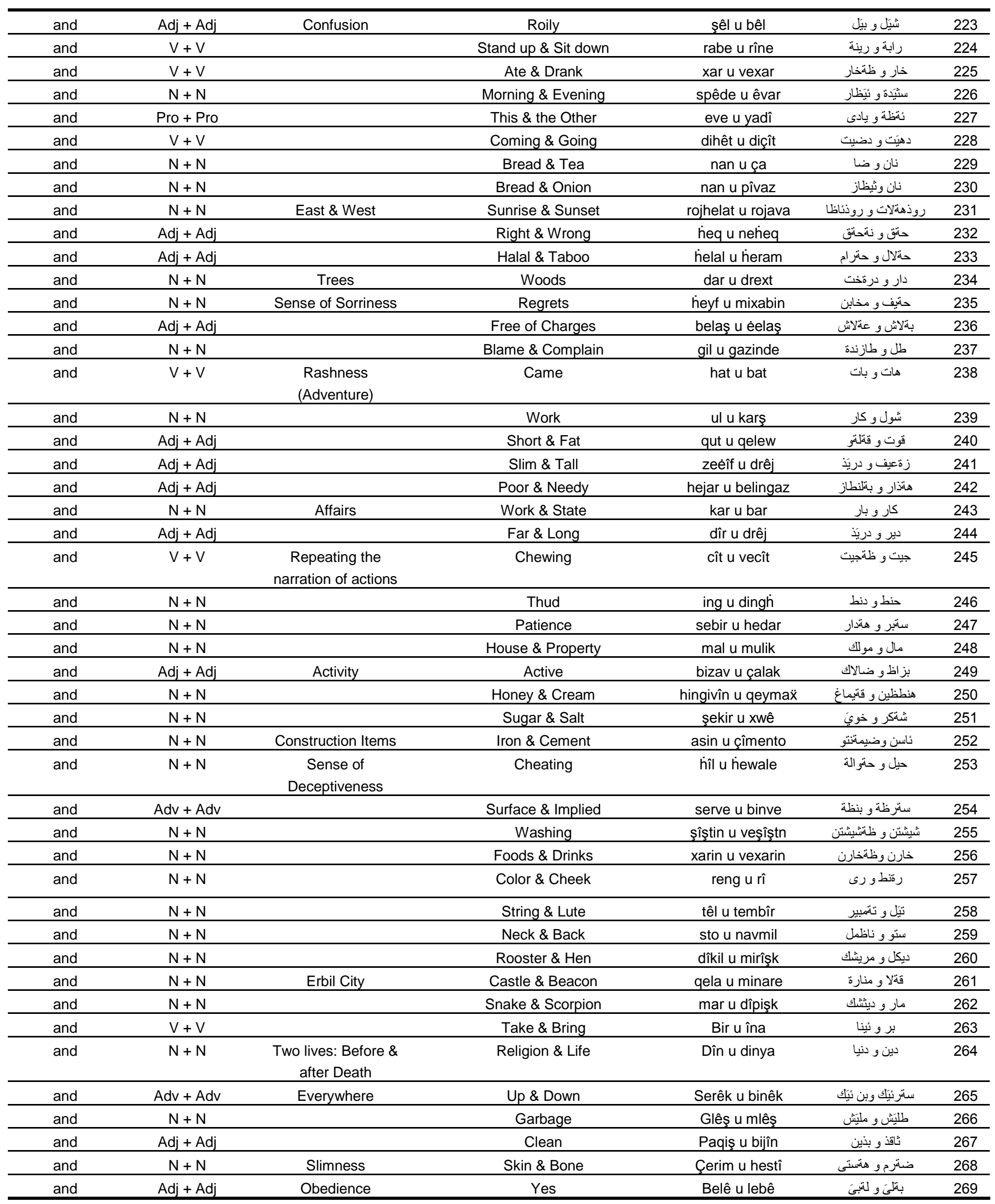




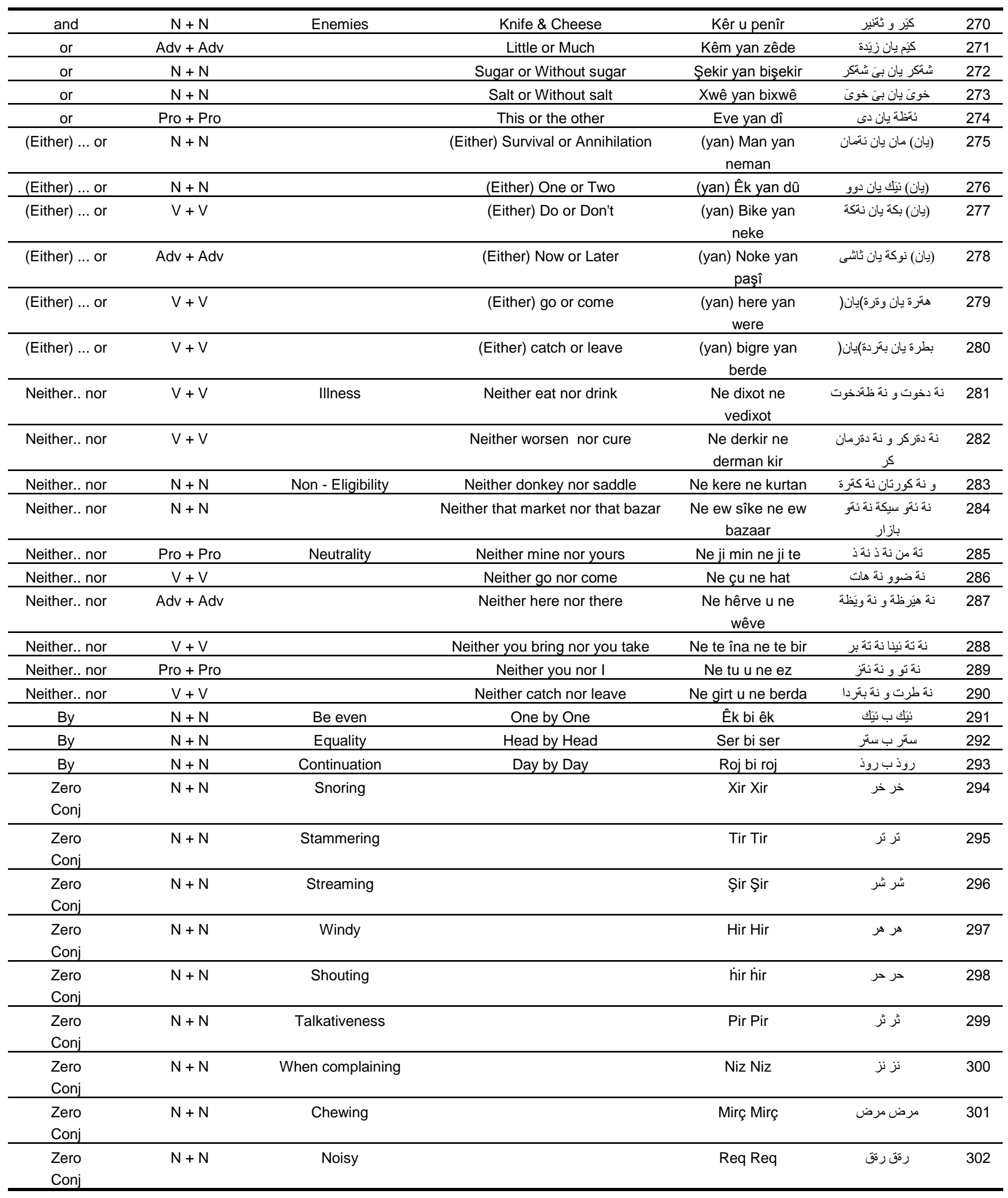




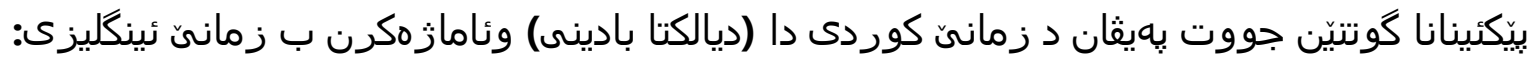

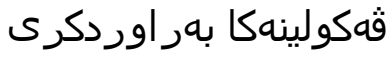

يوخته

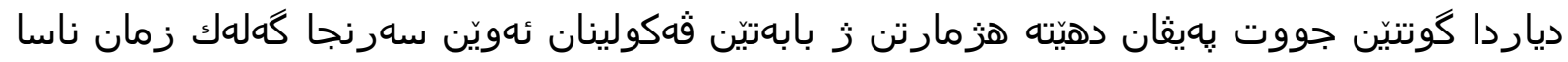

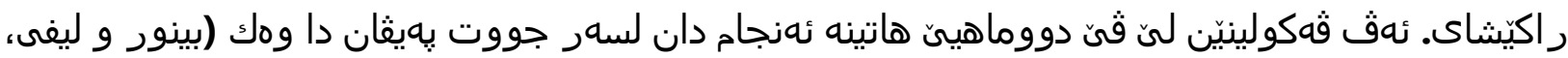

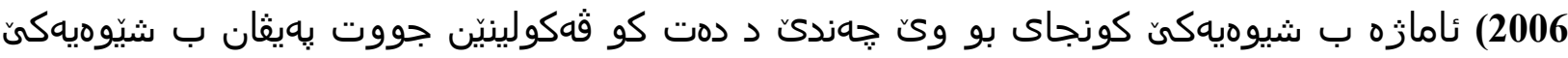

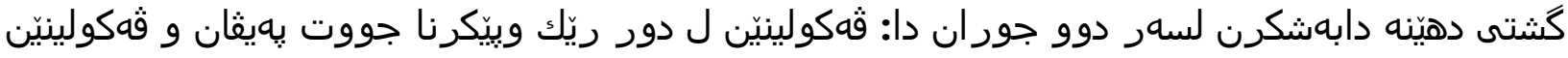

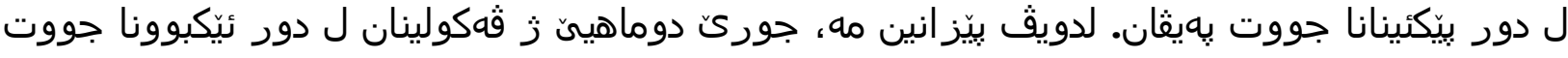

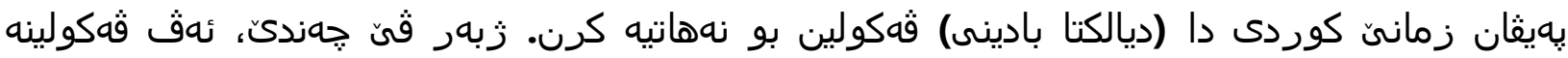

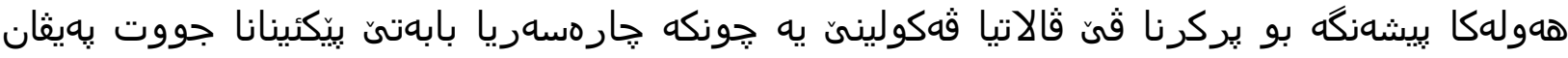

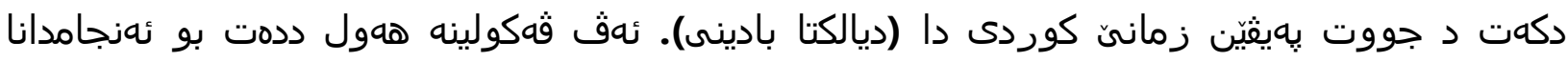

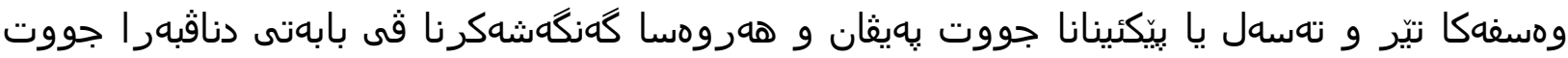

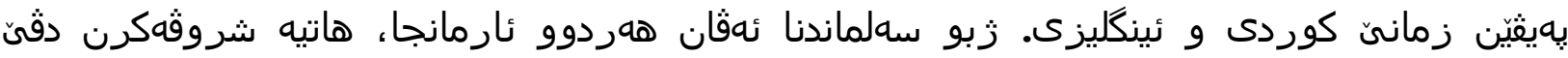

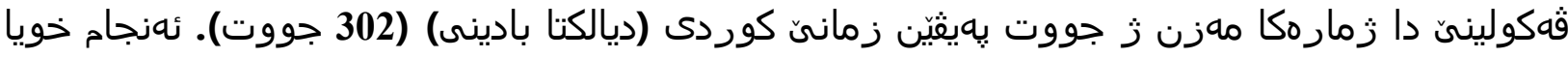

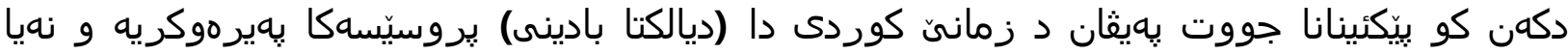

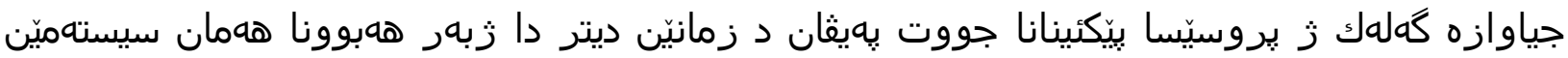

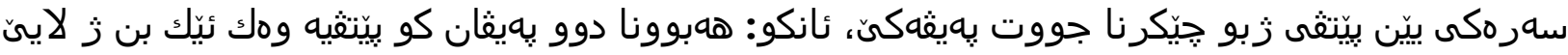

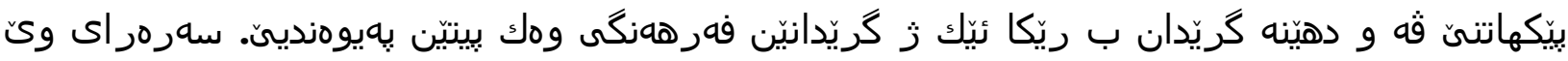

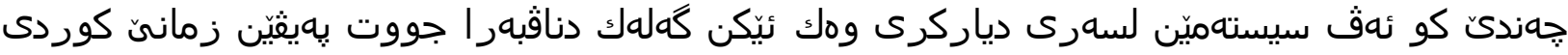

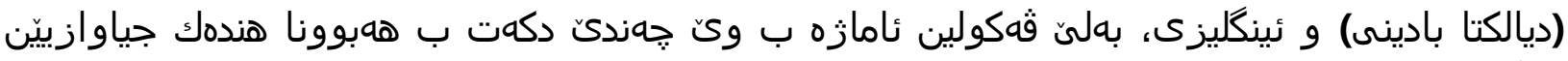

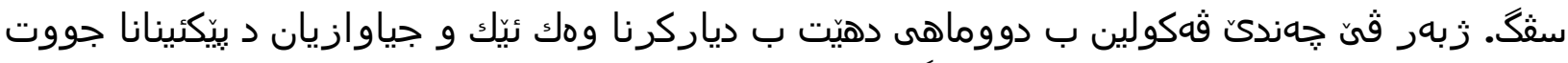
يهيقيَن زمانيّ كوردى (ديالكتا بادينى) و وئينكليزى دا.

تشكيل تعابير الثنائيات في اللغة الكردية (اللهجة البادينية) مع الإشارة إلى اللغة الإنكليزية: دراسة مقارنة 
تعتبر ظاهرة تعابيرالثنائيات من المواضيع البحثية التي استحوذت اهتمام العديد من اللغوبين. تشير إنير

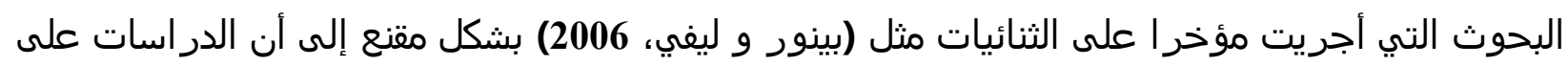

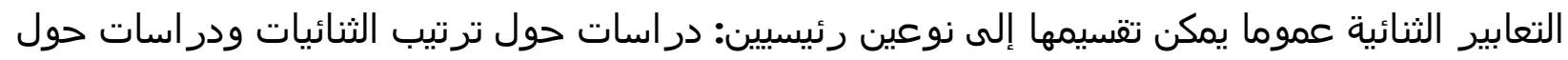

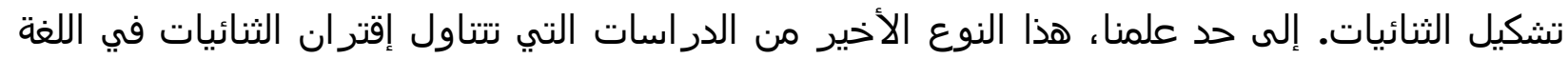

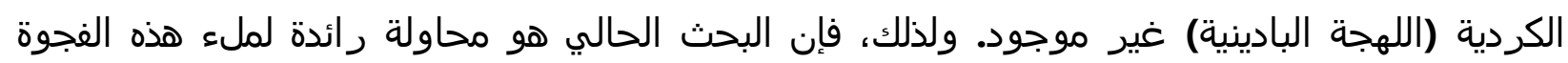

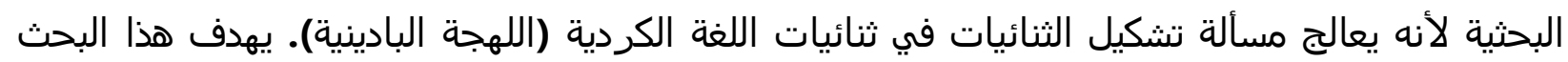

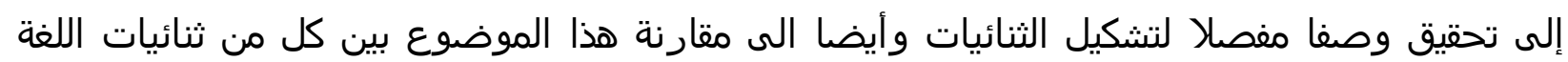

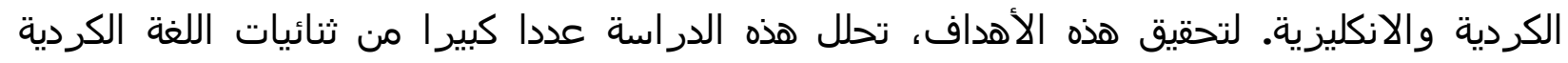

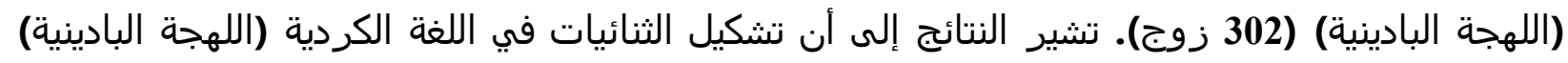

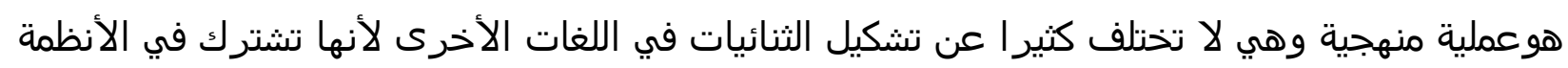

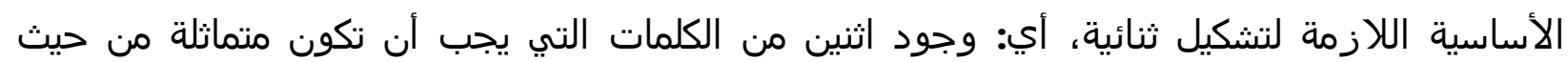

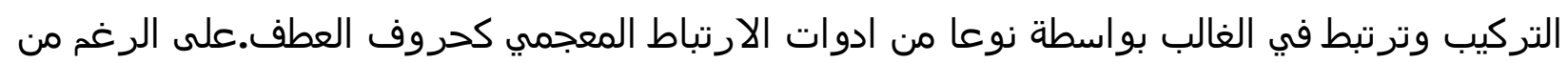

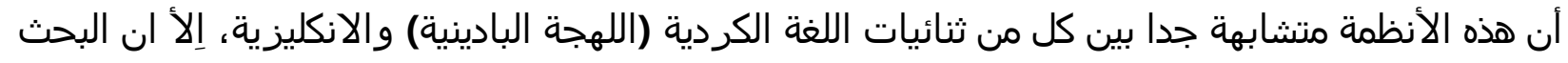

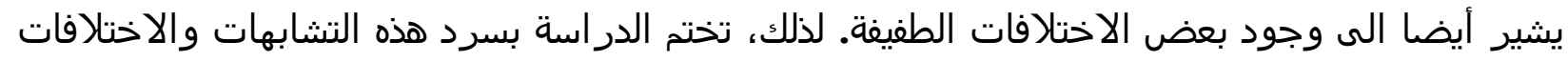

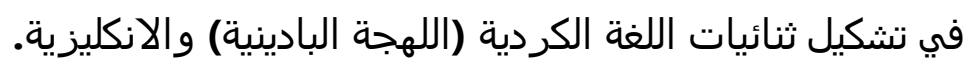

